\title{
Analysis of Students Competency in the Industrial Engineering Study Program South Aceh Polytechnic in Mastering the Concept Survey and Mapping Courses
}

\author{
M. Arinal Ihsan ${ }^{\mathrm{a}, 1, *}$, T. Sukma Achriadi $\mathrm{S}^{\mathrm{b}, 2}$ \\ ${ }^{a}$ Polytechnic of South Aceh, Merdeka Street, Komplek Reklamasi Pantai,Tapaktuan city, 23751, Indonesia \\ ${ }^{\mathrm{b}}$ Polytechnic of South Aceh, Merdeka Street, Komplek Reklamasi Pantai,Tapaktuan city, 23751, Indonesia \\ ${ }^{1}$ arynalfrank@gmail.com*; ${ }^{*}$ adimarlago@gmail.com
}

ARTICLE INFO

Article history:

Accepted

Keywords:

Competency

Students

Survey

Mapping

\section{ABSTRACT}

The problem formulation in this research are a) what is the level of students' ability in mastering the concept of Survey and mapping, and b) what difficulties do students experience in mastering the concept of Survey and Mapping. The research approach uses both quantitative and qualitative approaches. The research procedure goes through several stages, namely a) preparation stage, b) problem formulation stage, c) data collection stage, d) data analysis stage, and e) research results. The population in this study is students of the Industrial Engineering Study Program of South Aceh Polytechnic, while samples are students of semester II of the Academic Year 2020/2021 Industrial Engineering Study Program as many as 1 (one) class. Research is conducted at South Aceh Polytechnic. The instruments in this research are test questions and interview guidelines. Data collection techniques in this study used tests and interviews. Hypothesis testing of students' ability level in understanding survey and mapping subjects (tests) using right-hand $\mathrm{t}$-test at a significance level of 0.05 with acceptance criteria $\mathrm{H}_{0}$ if $t \geq$ $t_{(1-\alpha)}$ and $\mathrm{H}_{0}$ declined for $\mathrm{t}$ other values. Interview data were analyzed with the following stages 1) reducing the data, 2) presenting the data, and 3) concluding the data. External must be in the form of an accredited national journal ranked 1- 6 which is published in the Journal of Innovation and Engineering Technology with the information accepted/published. Technology Readiness Level (TKT) is 3. The results of data analysis performed at a significant level $\alpha=$ 0,05 gained $\mathrm{t}_{\text {Count }}=2,51$ and $\mathrm{t}_{\text {Table }}=1,73$, so $\mathrm{t}_{\text {Count }}>\mathrm{t}_{\text {Table }}$ or $2,51>1,73$. Thus, it can be concluded that students of the Industrial Engineering Study Program of South Aceh Polytechnic are able to master the concept of survey and mapping courses.

Copyright (C) 2021 Politeknik Aceh Selatan. All rights reserved.

\section{Introduction}

\section{A. Background}

Survey and Mapping is one of the subjects in the second semester of the South Aceh Polytechnic Industrial Engineering Study Program. The completion of the Survey and Mapping course depends on the readiness of students and the readiness of lecturers as instructors in their field. For students who are interested in studying surveys and mapping will carefully follow the course. Therefore, the lecturers strive to maintain and develop the interest or readiness to learn of their students. 
One of the government policies implemented by the Industrial Engineering Study Program is to implement curriculum revisions by using the KKNI curriculum. The researcher's preliminary study while teaching at the Industrial Engineering Study Program of South Aceh Polytechnic showed the low ability of students in understanding the subjects of Survey and Mapping. The results of the final exam of the 2019/2020 semester have not given the expected results. Therefore, researchers are interested in investigating the ability of students in understanding survey and mapping subjects.

The materials taught for survey and mapping courses are Definition of survey and mapping, Benefits of survey and mapping, Mining Survey, and Use of Theodolite. These are the chapters that apply many concepts that will continue to develop and not memorized material so that if students are not able to master the concept of the material, then it will be difficult to learn the next material. In other words, without mastering the basic concepts in full (correctly) can result in not being able to master the next concept. Therefore, students must properly understand the basic concepts of surveys and mapping in order to be able to master the concepts of advanced courses.

The author's findings while teaching in the Industrial Engineering program, many students are not able to properly master the basic concepts of surveys and mapping. It is observed that students are difficult and unable to master the basic concepts of surveys and mapping. Given the importance of mastery of survey and mapping subjects, then these subjects need to receive special attention. Furthermore, there is an adhesion to improve students' ability in understanding the concepts of survey and mapping courses.

\section{B. Problem Formulation}

The formulation of the problem in this study includes a) how to describe the level of student ability in mastering the concept of Survey and mapping subjects? and b) what difficulties do students experience in mastering the concept of Survey and Mapping courses?

\section{Research Objectives}

The purpose of this research is to a) determine the level of student ability in mastering the concept of Survey and Mapping, and b) to know any difficulties experienced by students in mastering the concept of Survey and Mapping.

\section{Literature Review}

\section{A. Learning}

Learning is a process of changing individual behavior through interaction with the environment. Learning is a process, an activity and not an outcome or goal. Learning is not just remembering, but broader than that, namely experiencing. According to [1], learning is a series of consciously performed activities or activities performed by a person to obtain a whole new behavioral change, as a result of his own experience in interaction with his environment. Then [2], learning indicates activities performed by a person consciously or intentionally. This activity refers to a person's activity in performing mental aspects that allow changes to occur in him. According to [3], learning is an activity performed by a person intentionally and in a conscious state to acquire a new concept, understanding or knowledge, with which a change of individual self can be formed both with his environment and with other individuals. According to [4], that learning is a process of change in behavior caused by experience and practice. Experience and practice are the activities of teachers as learners and the activities of students or learners as learners. These behavioral changes can be mental or physical.

Based on some of the above opinions, it can be concluded that learning is not just collecting knowledge. Learning is a mental process that occurs in a person, leading to the emergence of behavioral changes. Mental activity occurs because of the awareness in the individual's interaction with the environment.

\section{B. Learning Process}

Two important things that are part of the learning objectives are the formation of character by critical and creative thinking. For the development of this, we need to pay attention to the imagination and curiosity of students. Students should be given the opportunity to ask questions 
and argue, so it is expected that the learning process, especially in survey and mapping subjects is more meaningful.

In learning survey and mapping courses, lecturers should select and use strategies, approaches, methods, and techniques that involve students actively in learning, both mentally, physically, and socially. It is this principle of active learning that is expected to cultivate creative and critical learning goals. The strategy chosen in the teaching of survey and mapping subjects must be based on two things, namely the optimization of the interaction of all elements of learning and the optimization of the involvement of all the senses of students. The emphasis of survey and mapping course learning is not only on training skills and memorizing facts, but on understanding concepts.

Learning is a combination of teaching activities conducted by lecturers and learning activities conducted by students. In these learning activities, there is interaction between students, interaction between lecturers and students, as well as interaction between students and learning resources. It is hoped that with these interactions, students can actively build knowledge. According to [5] learning is an activity performed by the teacher in certain conditions, so that the cognitive, affective, and psychomotor of learners change for the better. In [6], learning is an effort made by learners with the aim of helping students to learn easily. Furthermore [7], concluding that learning is an effort made by teachers to create and help students to learn.

Descriptively, teaching is defined as the process of conveying information or knowledge from lecturers to students. The process of delivery is often also considered as a process of transferring knowledge. For the teaching process, as a process of imparting knowledge, will be more accurately defined by instilling knowledge. According to [8], that learning achievement is a process of activities performed by a person that produces a new behavioral change as a result of interaction with his environment. According to [9], in carrying out the teaching -learning process, it is necessary to have an evaluation that will later be used as a measure of the maximum that students have achieved after doing learning activities, for a specified time.

\section{Learning Achievement and Factors Affecting It}

In the teaching process, learning and learning performance play an important role. Learning is a process of change, that is, changes in behavior as a result of interaction with the environment in meeting the needs of life, while learning achievement is the result of the learning process. Learning activities are the most robust activities in the entire educational process. This means that the success or failure of the achievement of educational goals depends on how the learning process experienced by students as students.

Factors that affect a person's learning achievement are generally classified into two parts, namely internal factors and external factors. Internal factors are factors that come from within the individual himself, which include physical, psychological, and fatigue factors. External factors are things or situations that come from outside the individual. External factors can be divided into three groups, namely family, school and community environmental factors. According to [10], that the learning achievement achieved by students is essentially a reflection of learning efforts. In general, the better the learning effort, the better the performance achieved. Of course, this is not independent of the factors that affect it, such as interest, motivation, parents 'level of education, parents' income level, and so on.

\section{The Role of Lecturers in the Teaching -Learning Process}

The teaching -learning process and student learning outcomes are largely determined by the role and competence of the lecturer. Competent lecturers will be better able to create an effective learning environment and will be better able to manage the classroom so that student learning outcomes are at an optimal level. According to [11], that lecturers who have good competence will be easy in carrying out the learning process and learning objectives can be achieved in accordance with what has been determined in the planning. Competent lecturers are able to create an effective learning environment, fun, and able to manage the classroom, so that student learning is at an optimal level. 


\section{E. Learning Difficulties}

According to [12], there are generally two factors that cause learning difficulties, namely: a) Internal factors of learners, namely things or circumstances that arise from within the learners themselves, and b) External factors, namely things or circumstances that come from outside the learner's self. According to [13], that efforts to help learning difficulties can only be made by teachers if the causative factors of the difficulties can be properly identified. Therefore, an understanding of the factors that cause students' learning difficulties is very important.

\section{F. Survey and Mapping Courses}

Survey and mapping courses provide skills in measuring and mapping land, determining the shape or relief of the ground surface and its area, determining the position of objects/points in a space and time and the position and monitoring of physical shapes, structures and work above or below the earth surface.

\section{Method}

\section{A. Approach}

To obtain data on students' ability in understanding survey and mapping subjects, the authors used quantitative and qualitative approaches. According to [14], quantitative research is more likely to be used to prove a phenomenon (hypothesis). Quantitative analysis uses data in the form of numbers from calculations and measurements. In [15], qualitative research is a research process conducted in a reasonable and natural manner in accordance with objective conditions in the field without any manipulation, as well as the type of data collected mainly qualitative data.

\section{B. Population and Sample}

The population in this study is students of the Industrial Engineering Study Program of South Aceh Polytechnic. The sample in the research is students of the Industrial Engineering Study Program semester II Academic Year 2020/2021 as many as 1 (one) class.

\section{Research Site}

This research was conducted in the Industrial Engineering Study Program of South Aceh Polytechnic. The selection of the research site because the researcher is a lecturer in the Study Program.

\section{Instruments}

This research instrument is a test question and interview guidelines. The test questions serve to obtain data on students 'abilities, while the interview guidelines are used to obtain data on students' difficulties in survey and mapping subjects. Tests are given after students have studied survey and mapping subjects.

\section{E. Data Gathering Technique}

Data collection techniques in this study used tests and interviews. Questions are given based on the current KKNI curriculum. In this case, the number of questions is 5 questions, where 2 questions with an easy level of difficulty, 2 questions with a medium level of difficulty, and 1 question with a high level of difficulty. The time given to complete the question is 90 minutes. Furthermore, the data will be confirmed by the criteria that have been set, where a student is called thorough study if he obtains a score of at least $65 \%$ of the total score.

\section{F. Data Analysis}

As for the steps in data analysis:

1. To create a list of frequency distributions with the same class length as in [16], use the steps:

a) Determine the range, i.e. by way of the largest data minus the smallest data.

b) Determine the number of interval classes $(\mathrm{k})$ required using the Sturges rule, thus:

While $n$ states the amount of data.

$$
\text { Class numbers }(k)=1+3,3 \log n
$$

c) Determine the class length of the interval $p$ by the formula 


$$
\mathrm{P}=\frac{\text { range }}{\text { Class numbers }}
$$

d) Select the end of the first interval class boundary.

2. Calculate the average value according to the formula:

$$
\overline{\mathrm{x}}=\frac{\sum \mathrm{f}_{\mathrm{i}} \mathrm{x}_{\mathrm{i}}}{\sum \mathrm{f}_{\mathrm{i}}}
$$

3. To calculate the variance $\left(\mathrm{S}^{2}\right)$ the formula is used:

$$
\mathrm{S}^{2}=\frac{\mathrm{n} \sum \mathrm{f}_{\mathrm{i}} \mathrm{x}_{\mathrm{i}}^{2}-\left(\sum \mathrm{f}_{\mathrm{i}} \mathrm{x}_{\mathrm{i}}\right)^{2}}{\mathrm{n}(\mathrm{n}-1)}
$$

Next tested the requirements of the t-test:

4. Normality of data distribution

where:

$$
\chi^{2}=\sum_{\mathrm{t}=1}^{\mathrm{k}} \frac{\left(\mathrm{O}_{\mathrm{i}}-\mathrm{E}_{\mathrm{i}}\right)^{2}}{\mathrm{E}_{\mathrm{i}}}
$$

$\chi^{2}:$ The chi-square test

$\mathrm{O}_{\mathrm{i}}$ : Frequency of observations

$\mathrm{E}_{\mathrm{i}}$ : Expected frequency

The above statistic has a chi-square distribution with $\mathrm{dk}=(\mathrm{k}-1)$. The testing criterion rejects $\mathrm{H}_{0}$ if $x^{2} \geq x^{2}{ }_{(1-\alpha)(k-1)}$, in the other hands $\mathrm{H}_{0}$ is preferable. Hypothesis testing using righthand side t-test at a significant level $\alpha=0,05$ by hypothesis:

$$
\begin{array}{ll}
\mathrm{H}_{0}: \mu_{1} \geq 65: & \begin{array}{l}
\text { Students are able to master the concept of survey and mapping courses. } \\
\mathrm{H}_{1}: \mu_{1}<65:
\end{array} \quad \begin{array}{l}
\text { Students have not been able to master the concept of survey and mapping } \\
\text { courses. }
\end{array}
\end{array}
$$

In this study taken $\mu_{0}=65$ which is a standard value to state that students have been able to master $65 \%$ of the material that has been taught. The test criteria are in accordance with the rules of the left, namely "Accepts $\mathrm{H}_{0}$ if $\mathrm{t} \geq \mathrm{t}_{(1-\alpha)}$ rejects $\mathrm{H}_{0}$ to another $t$.

where:

$$
\mathrm{t}=\frac{\overline{\mathrm{x}}-\mu_{0}}{\frac{\mathrm{s}}{\sqrt{\mathrm{n}}}}
$$

\footnotetext{
$\overline{\mathrm{x}}:$ mean

$\mathrm{S}:$ standard deviation

$\mathrm{N}$ : data amount.
}

The interview data were analyzed descriptively with the following stages 1) reducing the data, 2) presenting the data, and 3) concluding the data.

\section{G. Research Stages}

The stages performed in this study are as follows:

1. Preparation

In the preparation stage, the activities carried out are observation and literature study related to the level of ability of students of the Industrial Engineering Study Program of South Aceh Polytechnic.

2. Problem Formulation Stage

In the problem formulation stage, the activity performed is to formulate a research problem.

3. Data Collection Stage

In the data collection stage, the activity is to conduct tests for survey and mapping subjects and interviews to find out the difficulties experienced by students in mastering survey and mapping subjects.

4. Data Analysis Stage

In the stage of data analysis, the activity is to analyze student ability test data using t-test, while the interview results are analyzed using descriptive analysis. 


\section{Results and Discussion}

\section{A. Research Data}

The data obtained in this study comes from tests conducted on 19 students in the subject of Survey and Mapping in the Industrial Engineering Study Program of South Aceh Polytechnic. The data on students' ability to master the concept of Survey and Mapping subjects as in Table 1.

Table 1. Survey and Mapping Course Test Result Data

\begin{tabular}{cccccc}
\hline No. & Students 'code & Score & No. & Students 'code & Score \\
\hline 1 & Student 1 & 55 & 11 & Student 11 & 65 \\
2 & Student 2 & 60 & 12 & Student 12 & 52 \\
3 & Student 3 & 50 & 13 & Student 13 & 70 \\
4 & Student 4 & 55 & 14 & Student 14 & 80 \\
5 & Student 5 & 95 & 15 & Student 15 & 90 \\
6 & Student 6 & 75 & 16 & Student 16 & 80 \\
7 & Student 7 & 90 & 17 & Student 17 & 70 \\
8 & Student 8 & 85 & 18 & Student 18 & 75 \\
9 & Student 9 & 80 & 19 & Student 19 & 80 \\
10 & Student 10 & 75 & & & \\
\hline
\end{tabular}

The data in Table 1 are presented in the form of the following frequency distribution tables:

Table 2 List of Frequency Distribution of Data on Students' Ability to Master the Concept of Survey and Mapping Courses

\begin{tabular}{ccccccc}
\hline No & Test Score & $\begin{array}{c}\text { Frequency } \\
\left(\mathbf{f}_{\mathbf{i}}\right)\end{array}$ & mean $\left(\mathbf{x}_{\mathbf{i}}\right)$ & $\mathbf{x}_{\mathbf{i}}{ }^{2}$ & $\mathbf{f}_{\mathbf{i}} \mathbf{x}_{\mathbf{i}}$ & $\mathbf{f}_{\mathbf{i}} \mathbf{x}_{\mathbf{i}}{ }^{2}$ \\
\hline 1 & $50-57$ & 4 & 53,5 & 2862,25 & 214 & 11449 \\
2 & $58-65$ & 2 & 61,5 & 3782,25 & 123 & 7564,5 \\
3 & $66-73$ & 2 & 69,5 & 4830,25 & 139 & 9660,5 \\
4 & $74-81$ & 7 & 77,5 & 6006,25 & 542,5 & 42043,75 \\
5 & $82-89$ & 1 & 85,5 & 7310,25 & 85,5 & 7310,25 \\
6 & $90-97$ & 3 & 93,5 & 8742,25 & 280,5 & 26226,75 \\
& Amount & 19 & - & - & 1384,5 & 104254,75 \\
\hline
\end{tabular}

From Table 2 obtained the average value of data on students' ability in mastering the concept of Survey and Mapping subjects as follows:

$$
\overline{\mathrm{x}}=\frac{\sum \mathrm{f}_{\mathrm{i}} \mathrm{x}_{\mathrm{i}}}{\sum \mathrm{f}_{\mathrm{i}}}=\frac{1384,5}{19}=72,87
$$

The variants and standard deviations are as follows:

$\mathrm{S}^{2}=\frac{\mathrm{n} \sum \mathrm{f}_{\mathrm{i}} \mathrm{x}^{2}-\left(\sum \mathrm{f}_{\mathrm{i}} \mathrm{x}_{\mathrm{i}}\right)^{2}}{\mathrm{n}(\mathrm{n}-1)}$

$\mathrm{S}^{2}=\frac{(19)(104254,75)-(1384,5)^{2}}{19(19-1)}$

$\mathrm{S}^{2}=\frac{1980840,25-1916840,25}{347}$

$\mathrm{S}^{2}=187,13$

$\mathrm{S}=13,68$

The variance is $\mathrm{S}^{2}=187,13$ and standard deviation is $\mathrm{S}=13,68$.

\section{B. Normality Test}

The test of the normality of the data distribution of students' ability in mastering the concept of Survey and Mapping subjects aims to determine whether the data of this research comes 
from a normally distributed population or not. Based on previous calculations obtained $\bar{x}=72,87$, variance $S^{2}=187,13$ and standard deviation $S=13,68$. Next it is necessary to determine the boundaries of the interval classes to calculate the area under the normal curve for each interval class.

Table 3 Test of Normality of Data Distribution of Students' Ability to Master the Concept of Survey and Mapping Courses

\begin{tabular}{ccccccc}
\hline Test Score & $\begin{array}{c}\text { Class border } \\
(\mathbf{x})\end{array}$ & $\boldsymbol{Z}$ - Score & margin & range & $\begin{array}{c}\text { Expected } \\
\text { Frequency } \\
\left(\mathbf{E}_{\mathbf{i}}\right)\end{array}$ & $\begin{array}{c}\text { Observed } \\
\text { Frequency } \\
\left(\mathbf{O}_{\mathbf{i}}\right)\end{array}$ \\
\hline $50-57$ & 49,5 & $-1,71$ & 0,4564 & 0,0878 & 1,6682 & 4 \\
$58-65$ & 57,5 & $-1,12$ & 0,3686 & 0,1632 & 3,1008 & 2 \\
$66-73$ & 65,5 & $-0,54$ & 0,2054 & 0,2253 & 4,2807 & 2 \\
$74-81$ & 73,5 & 0,05 & 0,0199 & 0,2158 & 4,1002 & 7 \\
$82-89$ & 81,5 & 0,63 & 0,2357 & 0,1531 & 2,9089 & 1 \\
$90-97$ & 89,5 & 1,22 & 0,3888 & 0,0753 & 1,4307 & 3 \\
& 97,5 & 1,80 & 0,4641 & 0,9205 & 17,5 & 19 \\
\hline
\end{tabular}

Description:

a) $Z$ = class border

b) $Z$-score $=\frac{x-\bar{x}}{s}$

c) The area of the normal curve can be seen in the table Z-score in F list

d) $E_{i}=$ The area of each interval class x data amount

then the calculated Chi-Square value is as follows:

$$
\begin{aligned}
& \chi^{2}=\sum_{i=1}^{\mathrm{k}} \frac{\left(\mathrm{O}_{\mathrm{i}}-\mathrm{E}_{\mathrm{i}}\right)^{2}}{\mathrm{E}_{\mathrm{i}}} \\
& \chi^{2}=2,8004+0,3908+1,2151+1,0508+1,2527+1,7213 \\
& \chi^{2}=7,4311 \\
& \chi^{2}=7,43
\end{aligned}
$$

To a significant degree $\alpha=0,05$ and classes $\mathrm{k}=6$, then a degree of freedom is obtained (dk) for the Chi-Square distribution the magnitude is $\mathrm{dk}=6-3=3$, from the Chi-Square table $\chi_{0,05(3)}^{2}=7,81$. Because of $\chi_{\text {hitung }}^{2}<\chi^{2}$ tahel that is $7,43<7,81$ so $\mathrm{H}_{0}$ accepted and it can be concluded that the distribution of Student Ability Data to Master the Concept of Survey and Mapping Courses follows the normal distribution.

\section{Hypothesis Testing}

Hypothesis testing using left-sided t-test at a significant level $\alpha=0,05$ and $\mathrm{dk}=\mathrm{n}-1$ with hypotheses:

$\mathrm{H}_{0}: \mu_{1} \geq 65$ : Students are able to master the concept of survey and mapping courses $\mathrm{H}_{1}: \mu_{1}<65: \begin{aligned} & \text { Students have not been able to master the concept of survey and mapping } \\ & \text { courses }\end{aligned}$ 
In this study $\mu_{0}=65$ taken which is a standard value to state that students have been able to master $65 \%$ of the material that has been taught. Testing criteria in accordance with the rules of the left, namely "Accept $\mathrm{H}_{0}$ if $t_{\text {Count }} \geq t_{(1-\alpha)(n-1)}$ and reject $\mathrm{H}_{0}$ to other $t$ value.

With:

$$
\mathrm{t}=\frac{\overline{\mathrm{x}}-\mu_{0}}{\frac{\mathrm{S}}{\sqrt{\mathrm{n}}}}
$$

$\overline{\mathrm{x}}:$ mean

$\mathrm{S}:$ Standard deviation

$\mathrm{N}$ : data amount.

The results of data analysis obtained that:

$$
\mathrm{t}=\frac{72,87-65}{\frac{13,68}{\sqrt{19}}}
$$

$$
\mathrm{t}=\frac{7,87}{\frac{13,68}{4,36}}
$$

$$
\mathrm{t}=\frac{7,87}{3,14}
$$$$
\mathrm{t}=2,51
$$

Based on the testing criteria of the left side that accept $\mathrm{H}_{0}$ if $t_{\text {Count }} \geq t_{(1-\alpha)}$ and reject $\mathrm{H}_{0}$ to other $t$. From the results of hypothesis testing it is obtained that $t_{\text {Count }} \geq t_{(0,95)(18)}$ or $2,51 \geq 1,73$. Based on these results, it can be concluded that "Students of the Industrial Engineering Study Program of South Aceh Polytechnic are able to master the concept of survey and mapping courses".

The results of the interview obtained difficulties and the causes of difficulties experienced by students in answering test questions are a) The tendency of students to study material or materials that contain calculations without paying attention to memorized material, b) The forgetfulness of students caused by lack of focus of students when the material is delivered in class, c) Mistakes in the learning process made by students. Students learn by using a fast method overnight, so that not all materials can be studied overnight, d) Errors in students in using formulas, and e) Errors in inputting values - variables in the formula.

\section{Conclusion}

Based on the data analysis conducted it can be concluded that:

1. Students of the Industrial Engineering Study Program of South Aceh Polytechnic are able to master the concept of survey and mapping courses.

2. The results of the interview obtained difficulties and causes of difficulties experienced by students in answering test questions that is:

a) Students do not study the material as a whole, whether the material contains a count or not

b) The forgetfulness of students caused by the lack of focus of students when the material is presented in class.

c) Irregular independent learning process.

d) Students' mistakes in using the formula.

e) Error in inputting variable values in the formula.

Based on the above conclusions, the author's suggestion is that for each lecturer of South Aceh Polytechnic always monitor the development and ability of students in the teaching and learning process, so that for the next learning process can be applied a constructive action with the aim of improving students' abilities of the subjects taught.

\section{Acknowledgment}


The author would like to thank KEMDIKBUD-RISTEK DIKTI who has provided a research budget for beginner lecturers. In addition, the author also thanked LLDIKTI13 who has facilitated the implementation of this research. The author also thanked the Director of South Aceh Polytechnic, LPPM, and the Chairman of the Industrial Engineering Study Program who have helped both energy and thinking in completing the research. In particular, the author would like to thank the lecturers of South Aceh Polytechnic who have helped and supported the implementation and completion of this research.

\section{References}

[1] Kundiati, Anggo, M. 2016. Peran Guru dalam Pembelajaran Geografi pada Siswa Kelas $\mathrm{X}^{\mathrm{A}}$ SMA Negeri 1 Kaledupa. Jurnal Penelitian Pendidikan Geografi, 1(1), 1 November 2016, pISSN 2477-8192, e-ISSN 2502-2776. Universitas Halu Oleo.

[2] Pane, A, Dasopang, M. D. 2017. Belajar dan Pembelajaran. Jurnal Kajian Ilmu-Ilmu Keislaman, 3(2), Desember 2017, e-ISSN 2460-2345, p-ISSN 2442-6997. IAIN Padang Sidempuan.

[3] Wandini, R. R, Sinaga, M. R. 2018. Games Pak Pos Membawa Surat pada Sintax Model Pembelajaran Tematik. Jurnal Raudhah, 6(1), Januari-Juni 2018, ISSN 2338-2163. Universitas Negeri Islam Sumatera Utara.

[4] Sunhaji. 2014. Konsep Manajemen Kelas dan Implikasinya Dalam Pembelajaran. Jurnal Kependidikan, 2(2), 2 November 2014, e-ISSN 2580-5533, p-ISSN 2580-5525. IAIN Purwokerto.

[5] Yusuf, B. B. 2018. Konsep dan Indikator Pembelajaran Efektif. Jurnal Kajian Pembelajaran dan keilmuan, 1(2), Oktober 2017-Maret 2018. Universitas Tanjungpura.

[6] Asyhar. 2011. Kreatif Mengembangkan Media Pembelajaran. Jakarta: Gaung Persada (GP) Press Jakarta.

[7] Atapukang, N. 2016. Kreatif Membelajarkan Pembelajar dengan Menggunakan Media Pembelajaran yang Tepat Sebagai Solusi dalam Berkomunikasi. Jurnal Media Komunikasi Geografi, 17(2), Desember 2016, ISSN 0216-8138. Unversitas Nusa Cendana.

[8] Hasibuan, A.A. 2018. Kontribusi Lingkungan Belajar dan Proses Pembelajaran Terhadap Prestasi Belajar Siswa di Sekolah. Jurnal Tarbiyah, 25(2), Juli-Desember 2018, p-ISSN: 08542627, e-ISSN: 2597-4270. UIN Sumatera Utara Medan.

[9] Lestari, P, Hudaya, A. 2018. Penerapan Model Quantum Teaching Sebagai Upaya Meningkatkan Hasil Belajar Siswa pada Mata Pelajaran IPS Kelas VIII SMP PGRI 3 Jakarta. Research and Development Journal Of Education, 5(1), 1 Oktober 2018, ISSN 2406-9744. Universitas Indraprasta PGRI.

[10] Mustamin, S.H, Sulasteri, S. 2013. Faktor-Faktor yang Mempengaruhi Prestasi Belajar Mahasiswa Jurusan Pendidikan Matematika Fakultas Tarbiyah dan Keguruan UIN Alauddin Makassar. Jurnal Matematika dan Pembelajaran (MAPAN), 1(1), Desember 2013, 151-177. UIN Alauddin Makassar.

[11] Winata, K. A, dkk. 2020. Peran Dosen dalam Pembelajaran Pendidikan Pancasila dan Kewarganegaraan untuk Mendukung Program Moderasi Beragama. Jurnal Pendidikan, 8(2), Tahun 2020, ISSN: 2337-7607 e-ISSN: 2337-7593.

[12] Syah, M. 2012. Psikologi Belajar. PT Raja Grafindo Persada, Jakarta.

[13] Ixganda, O, Suwahyono. 2015. Analisis Deskriptif Faktor Penyebab Kesulitan Belajar pada Mata Pelajaran Chassis dan Pemindah Daya Siswa Kelas XI Program Keahlian Teknik Kendaraan Ringan. Jurnal Pendidikan Teknik Mesin, 15(2), Desember 2015, 103-108, ISSN 1412-1247. Universitas Negeri Semarang.

[14] Hermawan, H. 2018. Metode Kuantitatif untuk Riset Bidang kepariwisataan. Versi Online: www.osf.io/ybsw9/, DOI: 10.17605/OSF.IO/YBSW9. Yogyakarta.

[15] Aresti Novita S.P dkk. 2017. Penerapan Pendekatan Contextual Teaching and Learning (CTL) untuk Meningkatkan Keaktifan dan Kemampuan Koneksi Matematis Siswa Kelas VIII F SMP 
Negeri 1 Jaten Tahun Pelajaran 2015/2016. Jurnal Pendidikan Matematika dan Matematika (JPMM) Volume 1(2), 92-109, September 2017. Program Studi Pendidikan Matematika: UNS. [16] Sudjana. 2005. Metoda Statistika. Bandung: Tarsito. 